\title{
State Criminal Justice Machinery Employed to Silence Political Dissidents: The Ongoing Case of Little Rock Reed Little Rock Reed
}

It is our belief that Little Rock Reed, a part Lakota man and sundancer who has committed his life to working for the self-determination and the religious rights of the aboriginal peoples of this land, has been targeted by the Ohio government to be imprisoned, and possibly murdered, in order to silence his voice which speaks to the injustices perpetrated on the aboriginal peoples and particularly our men, women and children who are incarcerated throughout this land.

We demand that the government conduct a fair and unbiased investigation into the circumstances relating to the current imprisonment of this man so that he may be free to continue doing the work that Tunkasila has put in his heart to do. If such an investigation is not done, this relative's imprisonment, much like the imprisonment of Leonard Peltier, will stand as a symbol of the injustices meted out by the white man's government against our people who simply wish to live in accordance with the traditional teachings given to us by our grandfathers, and to them by Wakan Tanka, the Creator.

-- Traditional Circle of Elders

Pine Ridge Indian Reservation

September 1994

The above demand, signed by 65 of the traditional leaders of the Oglala Lakota Nation, exemplifies similar demands that were ignored by the governors of New Mexico and Ohio -- demands made by various human rights/prisoners' rights organizations, the National Lawyers Guild, United States Senator Pete Domenici, hundreds of New Mexico and Ohio citizens, and various attorneys and professors throughout the United States and Canada. Because these governors refused to investigate and chose instead to have Little Rock extradited from New Mexico to Ohio, Little Rock fought extradition to Ohio in the New Mexico district court. Following two months of hearings, New Mexico District Court Judge Peggy Nelson ordered Little Rock's immediate release from jail, ruling that he and his attorneys proved beyond a reasonable doubt that the state of Ohio seeks to extradite, imprison and brutalize him for speaking and writing about human rights abuses against prisoners in general and Native prisoners in particular. In her 17 page decision, Judge Nelson declared that Ohio prison and parole officials' pursuit of Little Rock's extradition and imprisonment "... is premised on the desire to silence his voice." ${ }^{1}$ In the extradition hearings, Little Rock and his attorneys ${ }^{2}$ presented uncontroverted evidence indicating that the Ohio officials violated a long list of laws, including, but not limited to, Ohio and federal constitutional guarantees of freedom of speech, the right to petition the government for redress of grievances, the right to privacy, due process of the law, equal protection of the law, the right to be free from cruel and unusual punishment, and corresponding statutory and administrative laws. Additionally, they violated the New Mexico and Ohio Uniform Criminal Extradition Acts, and committed numerous criminal violations, including conspiracy, coercion, false imprisonment, dereliction of duty, interfering with civil rights, obstruction of justice, tampering with evidence, perjury, and Ohio's Corrupt Activity Act. 
Under Ohio law, these last three violations are third degree felonies with severe penalties of imprisonment. Section 2921.11 of the Ohio Revised Code states: "No person, in any official proceeding, shall knowingly make a false statement under oath or affirmation, or knowingly swear or affirm the truth of a false statement previously made, when either statement is material.... Whoever violates this section is guilty of perjury, a felony of the third degree."

Section 2921.12 of the Ohio Revised Code states: "No person, knowing that an official proceeding or investigation is in progress, or is about to be or likely to be instituted, shall ... [m]ake, present or use any record, document, or thing, knowing it to be false and with purpose to mislead a public official who is or may be engaged in such proceeding or investigation, or with purpose to corrupt the outcome of any such proceeding or investigation.... Whoever violates this section is guilty of tampering with evidence, a felony of the third degree."

A violation of the above two laws by public officials constitutes a violation of section 2923.31 of the Ohio Revised Code (the Corrupt Activity Act. Here is how these laws were specifically violated by two of the key players in Ohio's conspiracy against Little Rock:

(1) In a letter to the Taos, New Mexico, District Attorney's Office dated September 27, 1994, Jim Hathaway, an APA case analyst, claimed, among other falsehoods, that Little Rock's extradition was sought primarily because he had charges pending in Kentucky, and that Little Rock had two outstanding warrants for his arrest in Cincinnati, Ohio and Covington, Kentucky, "... verified as active on this date." These claims were proven to be false in the hearings. The proof of falsity came in the form of certified court clerk documents from Cincinnati and Covington. Moreover, according to uncontroverted testimony at the New Mexico hearings, Hathaway acknowledged to the Kentucky court clerk that he knew there was no outstanding warrant at the time he wrote the letter.

(2) APA acting Chief Jill Goldhart, in a sworn statement seeking Little Rock's extradition, stated that Little Rock will be charged with "... failing to report an arrest [while on parole] and involving himself in further criminal activity." The uncontroverted evidence, however, proved that Little Rock had never been arrested while on parole as claimed by Goldhart. Additionally, the evidence established that Little Rock has no pending criminal charges of any kind in Ohio, Kentucky or any other state. Moreover, the evidence indicated that Little Rock has not involved himself in any "further criminal activity", nor did the governor's extradition warrant or its annexed papers contain any facts (much less evidence) supporting this false allegation against Little Rock.

What is striking about this ongoing case is that the New Mexico Attorney General's Office, on behalf of Ohio, has appealed Judge Nelson's decision to the New Mexico Supreme Court, arguing that Ohio officials' criminal and civil violations are "irrelevant." In the appeal brief, the Attorney General admits that "... throughout the evidentiary presentation in these extradition proceedings, [Little Rock] presented considerable evidence concerning his ... mistreatment by Ohio and New Mexico authorities, improper motive and wrongdoing by Ohio corrections and parole personnel, his struggle to urge prisoner issues and the duress which required him to abscond from parole supervision in Ohio." 
Immediately following this admission, however, the Attorney General argues that this "considerable evidence" is entirely "irrelevant" because when a state invokes the Extradition Clause of the U.S. Constitution to capture an alleged fugitive, the targeted individual retains no right to present evidence of wrong-doing by the state officials demanding extradition (ironically, this repressive position is fully supported by U.S. Supreme Court precedent regarding extradition proceedings, and is consistent with current U.S. public policy).

Clearly, this case has broad ramifications for social activists across the country, for if Little Rock can be imprisoned and brutalized for demanding government accountability, anyone can.

It is for this reason that we seek our U.S. readers' support. We call upon you to join those of us who demand government accountability in cases like Little Rock's. Today there are more than 200 political prisoners in the United States. The only thing that distinguishes Little Rock's case from all the others is that Little Rock was fortunate enough to have a judge who was willing to review the evidence and rule according to the demands of justice. Unfortunately, without massive public outcry, her decision will in all likelihood be overruled by the higher courts because of the standing policy on interstate extradition which forbids the courts from reviewing evidence of bad faith motives by states demanding extradition of alleged fugitives (this policy is not unlike those of other regimes condemned by the United States).

At this time, Little Rock is being represented by the New Mexico Public Defender's Office in responding to the state's appeal, as he can no longer afford attorneys' fees. His responsive brief is being accompanied by a supporting brief by the National Lawyers Guild (amazingly, organizations such as the American Civil Liberties Union do not support this first amendment case).

Additionally, Little Rock has filed a petition with the Ohio Supreme Court asking that the court order the APA and Ohio Governor Voinovich to cease and desist with their attempts to have Little Rock arrested and extradited. Little Rock does not expect a favorable decision by the Ohio Supreme Court because its members are friends of Governor Voinovich. However, a Columbus, Ohio civil rights attorney has agreed to represent Little Rock in a lawsuit against all these officials for the systematic deprivation of his civil rights. Little Rock says that if he is awarded monetary damages as a result of this lawsuit, whatever is left after paying his debts (legal expenses) will be given to the Center for Advocacy of Human Rights (CAHR) to be used in the battle for prisoners' rights and the rights of Native Americans.

Any donations to help allay the costs of these efforts to obtain justice for Little Rock would be deeply appreciated and are tax deductible if sent to the CAHR. For more information on how you can support these efforts, please write and send a SASE to the CAHR, P.O. Box 880, Ranchos de Taos, NM 87557-0880, or call the CAHR at (505) 7510197 (the Center cannot return long distance calls direct due to lack of funds).

Thank you for your support. 


\section{ENDNOTES}

1 This is the first case in U.S. history in which a court of law has given such express recognition to a prisoner as a political prisoner. For a full account of this case, see Journal of Prisoners on Prisons, 1993. Vol. 5:1.

2 Little Rock was represented by Taos attorney John Paternoster and Deborah Garlin, president of the Center for Advocacy of Human Rights. 